\title{
Impacts of Climate Change on Livestock Location in the US: A Statistical Analysis
}

\author{
Minglu Wang ${ }^{1}$ (D) and Bruce A. McCarl ${ }^{2, *}$ \\ 1 School of Public Finance and Taxation, Southwestern University of Finance and Economics, \\ Chengdu 611130, China; wangml1120@gmail.com \\ 2 Department of Agricultural Economics, Texas A\&M University, 2124 TAMU, 600 John Kimbrough Blvd, \\ College Station, TX 77843, USA \\ * Correspondence: brucemccarl@gmail.com
}

Citation: Wang, M.; McCarl, B.A. Impacts of Climate Change on Livestock Location in the US: A Statistical Analysis. Land 2021, 10, 1260. https://doi.org/10.3390/ land 10111260

Academic Editor: Luca Salvati

Received: 15 September 2021

Accepted: 17 November 2021

Published: 18 November 2021

Publisher's Note: MDPI stays neutral with regard to jurisdictional claims in published maps and institutional affiliations.

Copyright: (c) 2021 by the authors. Licensee MDPI, Basel, Switzerland. This article is an open access article distributed under the terms and conditions of the Creative Commons Attribution (CC BY) license (https:/ / creativecommons.org/licenses/by/ $4.0 /)$.

\begin{abstract}
Livestock production is a valuable part of US agriculture as it contributes $50 \%$ of total agricultural value. Climate change is likely a threat to livestock production, but research regarding the impact of climate change on livestock sectors is limited. This paper examines how climate change affects livestock mix and location. Specifically, we examine climate effects on grazing animals and, in particular, on beef cattle, dairy cattle, goats, and sheep. We examine this in the US based on county-level data by using fractional multinomial logit econometrics. Our results show that climate is an influential determinant of where livestock herds are located and species mix. The impacts of climate vary by species and region. We also find significant influences from geographic characteristics and animal product prices. Subsequently, we project how climate change would influence future livestock mix and location. It reveals a likely growth in beef cow land shares across most of the US with the largest gains in the northwest. We also find substitutions between species as climate change progresses with dairy cows exhibiting the largest reduction.
\end{abstract}

Keywords: climate change; land use; livestock species; adaptation; United States

\section{Introduction}

For the past half-century, the climate has been changing and exhibits increased temperatures, altered precipitation patterns, and increased frequency of extreme events [1], and this is expected to continue. Agriculture is sensitive to climate change, and effects have already been felt across the landscape [2]. However, the effects are not uniform, with some cold regions likely benefiting and some hot regions losing [3].

Livestock production is a valuable part of US agriculture, contributing $50 \%$ of total value [4]. According to the 2017 Census of Agriculture, the US beef cattle industry had 32.5 million beef cows in inventory and USD 77.2 billion in sales, accounting for $20 \%$ of total US agricultural sales [5]. The poultry industries were the next largest livestock commodity in the US, with production valued at around USD 49.2 billion, followed by hogs and pigs at USD 26.3 billion. The sales of milk products from dairy cattle totaled USD 36.7 billion, accounting for $9.5 \%$ of total US agriculture sales. Goats and sheep contributed USD 1.03 billion, with goats totaling 2.64 million head and sheep totaling 5.2 million head.

Grazing animals are likely to be more affected by climate change than confined livestock since they are directly exposed to the climate. Some species are heat tolerant, and some are cold resistant. Some may have a wider range of tolerable temperatures while some have rather narrow ones. For example, dairy cows' best range as measured by the thermo-neutral zone (TNZ) is estimated to range from 5 to $25^{\circ} \mathrm{C}$ [6]. Conditions hotter than the TNZ have negative effects on milk production, animal growth, fertility, and health among other effects altering hormonal status, nutrient absorption, and immune functions [7]. The economic loss caused by heat stress was estimated to be as high as USD 897 million for the dairy industry [8]. Cold stress is also a concern, causing dairy 
cows to increase their metabolic rate to supply more body heat which may increase dietary requirements. Beef cows may also suffer from both heat and cold stresses, requiring more energy for maintenance. However, findings indicate that beef productivity loss caused by varying temperatures is smaller than those for other animals because beef cows have lower metabolic rates and a wider TNZ range [8]. However, excess winter precipitation may increase housing needs [9]. Goats and sheep are considered to be heat tolerant, but their body reserves are not sufficient for adapting to multiple stressors such as thermal, nutritional, and walking stresses [10]. A remarkable drop in body sizes has been observed for sheep and goats from the northern to southern areas of the Mediterranean area [11].

Thus, the question of how to reduce the economic loss associated with climate change is critical for livestock producers. One option is altering operations to accommodate the local climate, and today this does not only involve adjustment to an altered local climate but also involves an evolving climate. In the literature, the adjustment to a changing climate is called adaptation [12]. Livestock producers have been observed to adapt by altering management, land usage, livestock species mix, crop/grassland mix, feeding patterns, housing, and shade provision [13-18].

Conceptually, we can view livestock management as a multi-stage decision process [19]. In the first stage, farmers choose whether or not to raise livestock. In the second stage, they choose the species mix to utilize and where to locate them. In the third stage, they choose stocking rates, diets to use, grazing intensity, supplemental feeding, housing, etc. All of this, we presume, is conducted in pursuit of profit maximization. Adaptive activities involve climate change accommodating altercations in the decisions across these stages including species mix, the spatial distribution of animals, and animal density/stocking rate.

Here, we explore part of the adaptive decision-making space by examining how US farmers adapt grazing livestock species mix to alternative climate conditions. In conducting this study, we examine US county-level data by using a multinomial logit model for land use shares of four major species-dairy cows, beef cows, goats, and sheep. We also project how future livestock mix and location alter under different climate change scenarios. Our resultant hypotheses guiding this study are presented in Table 1.

Table 1. Research hypotheses.

\begin{tabular}{cc}
\hline Hypotheses & Reasoning \\
\hline $\begin{array}{c}\text { 1. The share of each } \\
\text { livestock species has a } \\
\text { nonlinear relationship with } \\
\text { climate factors. }\end{array}$ & $\begin{array}{c}\text { Animals have optimal temperature ranges for growth and } \\
\text { comfort known as the thermoneutral zone (TNZ). Livestock yield } \\
\text { the highest productivity within the TNZ but may lose } \\
\text { profitability if the climate falls above or below that zone. Thus, } \\
\text { the share of each species is affected by climate factors. }\end{array}$ \\
$\begin{array}{c}\text { 2. Magnitudes of sensitivity } \\
\text { to climate vary by species. }\end{array}$ & $\begin{array}{c}\text { Different species have different TNZs, and their land use shifts } \\
\text { differentially under altered environmental factors. For example, } \\
\text { dairy cows milk yields may drop significantly under hot and wet } \\
\text { conditions while goats are more heat tolerant. }\end{array}$ \\
\hline $\begin{array}{c}\text { 3. Livestock share locations } \\
\text { will shift under } \\
\text { climate change. }\end{array}$ & $\begin{array}{c}\text { With climate change, the climate of some regions may become } \\
\text { favorable for a specific species while that of others may become } \\
\text { likely to cause greater heat stress or cold stress. Local farmers will } \\
\text { adapt to climate change by changing species land use shares. }\end{array}$ \\
\hline
\end{tabular}

This paper is organized as follows. The following section reviews prior literature researching farmers' adaption associated with livestock management. Section 3 provides a detailed description of the multinomial logit model and data used in the estimation. Section 4 presents the estimation results and projection results under different climate change scenarios. Section 5 concludes this paper. 


\section{Literature Review}

The effect of climate change on crop production locations has been frequently examined [20-23]. The prevalent finding is that climate change is causing crop production to shift to higher latitudes and/or elevations [18].

A few studies have examined effects on livestock land use and location. Some found that grassland would substitute for cropland when the climate is not beneficial for crop production [24-26]. Mu et al. [16] examined how climate affected land allocation to crops versus grazing at the US state level, finding $U$ and inverted $U$ shaped relationships with temperature and precipitation. Namely, as temperatures warm from low levels or rainfall increases from very dry conditions, land shifts from grassland to crops, but when temperatures or rainfall rise past thresholds, then land shifts out of croplands to grass. Seo and Mendelsohn [19] found that warming and drying would increase livestock ownership but that an increase in precipitation would decrease it. Mu et al. [27] projected that climate change would cause an increase in grazing land share in the Southern US and the inland pacific northwest but a decrease in the Northern US. However, US-wide studies of land allocation among livestock species have not been conducted.

Climate influences on species mix have been examined in a few regions $[19,28,29]$. Seo and Mendelsohn [19] found that in the probability of choosing beef and dairy cattle decreases as temperature increases in 10 African countries, with the probability of owning goats and sheep increasing. They also found that the probability of choosing chickens exhibits a hill-shaped response to temperature and that as precipitation increases, cattle and sheep decrease while goats and chickens increase. A related study conducted in South America generally found that a drying climate would increase sheep while decreasing beef cattle, dairy cattle, pigs, and chickens [29].

Breed choices have also been discussed as adaptation strategies [15,30,31]. Empirically, Zhang et al. [17] found substitutions between Bos indicus and more heat tolerant Bos Taurus breeds. Mader et al. [30] found positive impacts on beef cattle with increasing temperatures and negative impacts on milk production. They also suggested that animals can adapt to small changes in climate, but adjustments in management strategies are needed under larger changes.

Climate also influences decisions on herd size [32-35]. Farmers in Australia adapted to a hot arid climate by increasing sheep and beef cattle herd size [34]. In the US, the cattle stocking rate was found to decrease when summer temperature-humidity index increased [16]. However, no studies have used observed US herd data to examine the impact of climate change on farmers' decisions on livestock species mix and location. Moreover, most previous studies used either US state-level data to investigate adaptation [16] or county-level data to investigate regional adaptations $[17,36]$. Few studies have utilized county-level data to examine the climate effects nationwide. This paper will fill that gap.

\section{Methods and Data}

\subsection{Estimation Approach}

In order to examine how climate influences livestock land shares, we estimate an econometric model across grazing species. Specifically, we follow Seo et al. [29] and assume that farmers maximize profit $\pi^{*}$ as follows:

$$
\pi^{*}=\operatorname{Max} \sum_{j} \pi_{j}(C, G, E)
$$

where $\pi_{j}$ denotes the profit arising from raising species $j$, which is a function of climate $(C)$, geographic characteristics $(G)$, and economic conditions $(E)$.

In turn, the profit of species $j$ is calculated as follows:

$$
\pi_{j}=\pi\left(C, G, E \mid D_{j}=1\right)=P_{j} * Q_{j}(C, G, E)-\operatorname{cost}_{j}(C, G, E)
$$

where $D_{j}$ is a dummy variable indicating the species $j$ is chosen, $P_{j}$ is the price of the $j$ th type of livestock product, $Q_{j}$ is a production function where production depends on $C, G$, 
and $E$, and $\operatorname{cost}_{j}(C, G, E)$ is the production cost. In turn, the optimum production level $\left(Q_{j}^{*}\right)$ can be written as follows:

$$
Q_{j}^{*}=\operatorname{argmax} \pi_{j}(C, G, E)
$$

where $Q_{j}^{*}$ is the optimal livestock population that yields the highest profit.

In turn, the optimal proportional land share for livestock $j$ in county $i\left(s_{i j}^{*}\right)$ is as follows:

$$
s_{i j}^{*}=\frac{Q_{j}^{*} * A U E_{j} * G R_{i}}{\sum_{j} Q_{j}^{*} * A U E_{j} * G R_{i}}
$$

where $A U E_{j}$ is the animal unit equivalent for livestock species $j$. The AUE parameter adjusts for the fact that different grazing livestock species differ in size and converts livestock numbers to a common measure of animal units. One animal unit (AUE $=1)$ is defined as a $454 \mathrm{~kg}$ cow with an unweaned calf. In turn, following Redfearn and Bidwell [37], the amount of forage required by seven goats is equal to that used by the cow-calf pair (AUE $=0.17$ for a goat) as is the amount used by five sheep (AUE $=0.2$ for a sheep). $G R_{i}$ is the grazing rate for county $i=1, \ldots, N$, representing the grassland size per animal unit. The grazing rates on a state basis are drawn from FASOMGHG [38]. The numerator of the land share equation calculates the amount of grazing land that livestock species $j$ requires in county $i$. The denominator calculates the total amount of grazing land required by all livestock species in the county. Thus, $s_{i j}$ provides the share of grazing land used by each livestock species and, by construction, equals one when summed across all grazing livestock types.

The proportional land shares of livestock reflect the farmers' selection preferences toward species including climate adaptation. Adaptation to climate can be measured by the change in land share in response to a change in climate. If climate change causes one species to become less profitable relative to another, the farmer could adjust land share between species. Product prices and geographic factors would also have an influence. Given this, we estimate $s_{i j}^{*}$ as a function of $C, G$, and $E$.

To estimate this function, we use a fractional multinomial logistic regression that we estimate via the quasi-maximum likelihood (QML) following $[16,18,39,40]$. The resultant conditional means for the land shares equal the following:

$$
\mathrm{E}\left(s_{i j t} \mid \mathbf{x}_{i t}\right)=G_{j}\left(\mathbf{x}_{i t} ; \boldsymbol{\beta}\right)=\frac{\exp \left(\mathbf{x}_{i t} \boldsymbol{\beta}_{j}\right)}{\sum_{k=1}^{J} \exp \left(\mathbf{x}_{i t} \boldsymbol{\beta}_{k}\right)}, j=1, \ldots, J
$$

where $s_{i j t}$ is the optimal land share of livestock type $j$ in year $t=1, \ldots, T$, and county $i=1, \ldots, N$. $\mathbf{x}_{i t}$ is a vector of the $C, G$, and $E$ explanatory variables.

If we set livestock species $J$ to be the baseline livestock species by normalizing $\beta_{J}=0$, the conditional mean for the land share of the baseline livestock species $J$ is calculated as follows.

$$
\mathrm{E}\left(s_{i J t} \mid \mathbf{x}_{i t}\right)=G_{J}\left(\mathbf{x}_{i t} ; \boldsymbol{\beta}\right)=\frac{1}{1+\sum_{k=1}^{J-1} \exp \left(\mathbf{x}_{i t} \boldsymbol{\beta}_{k}\right)}
$$

Moreover, the conditional mean for the land share for other livestock is as follows.

$$
\mathrm{E}\left(s_{i j t} \mid \mathbf{x}_{i t}\right)=G_{j}\left(\mathbf{x}_{i t} ; \boldsymbol{\beta}\right)=\frac{\exp \left(\mathbf{x}_{i t} \boldsymbol{\beta}_{j}\right)}{1+\sum_{k=1}^{J-1} \exp \left(\mathbf{x}_{i t} \boldsymbol{\beta}_{k}\right)}, j=1, \ldots, J-1
$$

The above equations cause the conditional expected land shares to add up to one $\left(\sum_{j} s_{i j t}=1\right)$ and to fall between zero and one $\left(s_{i j t} \in(0,1)\right)$ given that $\operatorname{Pr}\left(s_{i j t}=0 \mid \mathbf{x}_{i t}\right) \geq 0$ and $\operatorname{Pr}\left(s_{i j t}=1 \mid \mathbf{x}_{i t}\right) \geq 0$ for $\left.j=1,2, \ldots, J\right)$. 
Additionally, we use the fractional multinomial logit since it avoids issues with the independence of irrelevant alternatives [40] and extreme zero and one values [41].

In the estimation, the quasi-maximum log-likelihood function is utilized following Papke and Wooldridge [42].

$$
l_{i t}(\boldsymbol{\beta})=\sum_{j}^{J} s_{i j t} \log \left[G_{j}\left(\mathbf{x}_{i t} ; \boldsymbol{\beta}\right)\right]
$$

To obtain the QML estimator for $\beta$, we maximize $l_{i t}(\beta)$ resulting in the first order condition for species $j$ land share in county $i$ as follows.

$$
\frac{\partial l_{i}(\boldsymbol{\beta})}{\partial \boldsymbol{\beta}_{j}}=\sum_{i=1}^{N} \mathbf{x}_{i t}^{\prime}\left[s_{i j t}-G_{j}\left(\mathbf{x}_{i t} ; \boldsymbol{\beta}\right)\right]=0
$$

That expression provides the marginal effects that a one-unit change in $\mathbf{x}$ has on the $\log$ of the probability of choosing a livestock species over the base species. In order to develop direct interpretations, following Long and Freese [43], we calculate the average marginal effects (AME). AME is interpreted as the marginal impact of one unit change in the explanatory variables on the land shares. Note that since the land shares always add up to one, this means that an increase in the land share for one species is accompanied by decreases in shares for the other species. Thus, the sum of marginal effects across all species is always zero. For continuous explanatory variables, the AME is given by the following:

$$
\frac{\partial \mathrm{E}\left[s_{i j t} \mid \mathbf{x}_{i t}\right]}{\partial \mathbf{x}_{i t}^{m}}=N^{-1} \sum_{i=1}^{N}\left(\beta_{j}^{m} G_{j}\left(\mathbf{x}_{i t} ; \boldsymbol{\beta}\right)-G_{j}\left(\mathbf{x}_{i t} ; \boldsymbol{\beta}\right) \sum_{k=1}^{J-1} G_{k}\left(\mathbf{x}_{i t} ; \boldsymbol{\beta}\right) \boldsymbol{\beta}_{k}^{m}\right)
$$

where $\mathbf{x}_{i t}^{m}$ is the value of $m$ th continuous explanatory variables in county $i$ for year $t . \boldsymbol{\beta}_{j}^{m}$ is the $m$ th coefficient within the estimated equation for livestock species $j$. For discrete explanatory variables, AME is calculated as follows.

$$
\frac{\Delta \mathrm{E}\left[s_{i j t} \mid \mathbf{x}_{i t}\right]}{\Delta \mathbf{x}_{i t}^{m}}=N^{-1} \sum_{i=1}^{N}\left(G\left(\mathbf{x}_{i t}^{-m} \boldsymbol{\beta}_{j}^{-m}+\boldsymbol{\beta}_{j}^{m}\right)-G\left(\mathbf{x}_{i t}^{-m} \boldsymbol{\beta}_{j}^{-m}\right)\right)
$$

Although the fractional multinomial logit model does not explicitly deal with the panel structure of the data, we include both regional and time-fixed effect dummy variables as conducted in the panel model.

$$
\mathrm{E}\left(s_{i j t} \mid \mathbf{x}_{i t} ; \boldsymbol{\beta}\right)=\frac{\exp \left(\mathbf{x}_{i t} \boldsymbol{\beta}_{j}+c_{i}+z_{t}\right)}{\sum_{k=1}^{J} \exp \left(\mathbf{x}_{i t} \boldsymbol{\beta}_{k}+c_{i}+z_{t}\right)}, j=1, \ldots, J
$$

Spatial fixed effects variables are included at a more aggregate regional level as adding them for all counties would eliminate much of the variation in the data and compromise our ability to estimate the effects of climate [44]. The regions we used are given in Table 2 and mapped in Figure 1. The region classification coincides with those used in FASOMGHG [38] and is also consistent with the boundaries of USDA farm production regions [45]. Regional fixed effects are included to account for regionally specific agriculture-related characteristics such as soils, production resources, transportation access, and policy factors that may influence the relative share of each livestock species. We also include a time-fixed effect to capture region-invariant but time-specific confounding factors such as technological progress. 
Table 2. Definition of US market regions used in fixed effects.

\begin{tabular}{cccc}
\hline Region & Market Region & & States \\
\hline \multirow{6}{*}{ East } & Corn Belt & CB & IL, IN, IA, MO, OH \\
& Lake States & LS & MI, MN, WI \\
& Northeast & NE & CT, DE, ME, MD, MA, NH, NJ, NY, PA, RI, VT, WV \\
& South Central & SC & AL, AR, KY, LA, MS, TN \\
& Southeast & SE & FL, GA, NC, SC, VA \\
\hline \multirow{6}{*}{ West } & Great Plains & GP & KS, NE, ND, SD \\
& Pacific Northwest & PNW & OR, WA \\
& Pacific Southwest & PSW & CA \\
& Rocky Mountains & RM & AZ, CO, ID, MT, NV, NM, UT, WY \\
& Southwest & SW & OK, TX \\
\hline
\end{tabular}

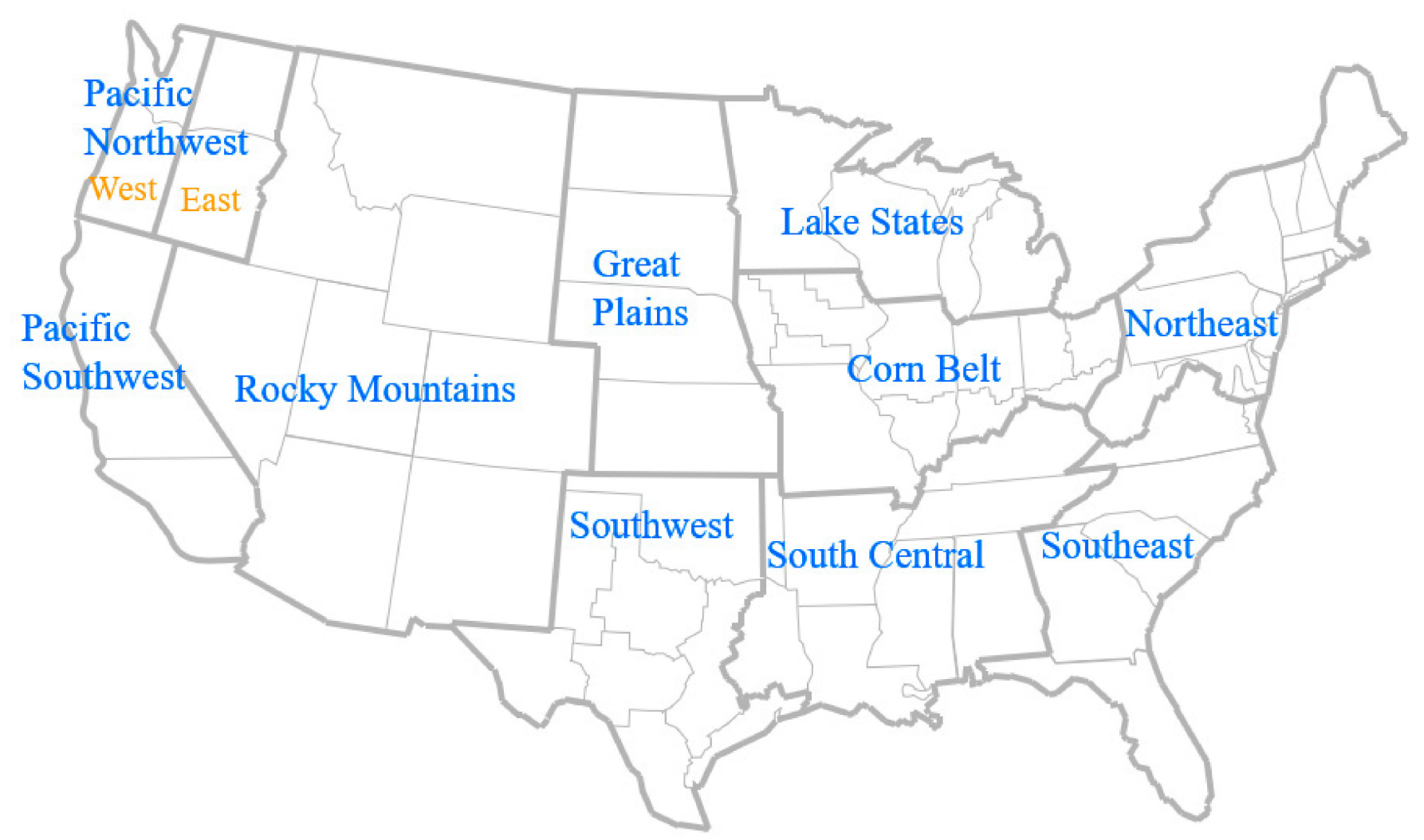

Figure 1. Map of US market regions used in fixed effects. Source: Adams et al. [38].

\subsection{Data}

We estimate our land share equation by using USDA county-level data on the inventory numbers of beef cows, dairy cows, goats, and sheep. In performing this, we realize that shifts in livestock species are longer-term decisions and occur in response to longer-term developments (as argued in Mu et al. [16]). Thus, we use longer time intervals between decisions, allowing time for adjustment. As a consequence, we use census data that are collected every five years for herd, geographic, and economic data [46] and three-year moving average climate data [47]. We believe this allows us to observe long-term species land use shifts in response to long-term climate movements.

The US county-level livestock inventory data were drawn from the Census of Agriculture that is released every five years and available in the USDA National Agricultural Statistics Service (NASS) [46]. The census years we used span from 1997 to 2017 (5 census years fell in that interval). For goats, 1997 data were not available. Land shares for dairy cows are only considered in the counties east of the Mississippi River since dairy cows are 
generally raised in confinement in the Western US. As a consequence, we also performed separate estimations for the Eastern and Western US. Table 3 summarizes the average land share by species and region. Beef cows are the most common species in most regions, followed by dairy cows, and then sheep, with goats being the smallest groups.

Table 3. Average land share of livestock by region.

\begin{tabular}{cccccc}
\hline Region & Market Region & Beef Cow & Dairy Cow & Goat & Sheep \\
\hline \multirow{5}{*}{ East } & CB & $75.36 \%$ & $19.05 \%$ & $1.86 \%$ & $3.73 \%$ \\
& LS & $39.80 \%$ & $53.76 \%$ & $1.94 \%$ & $4.50 \%$ \\
& NE & $42.29 \%$ & $46.03 \%$ & $4.07 \%$ & $7.61 \%$ \\
& SC & $92.64 \%$ & $4.08 \%$ & $2.22 \%$ & $1.05 \%$ \\
& SE & $83.25 \%$ & $8.09 \%$ & $5.60 \%$ & $3.05 \%$ \\
Total & $72.53 \%$ & $20.87 \%$ & $3.13 \%$ & $3.47 \%$ \\
\hline West & GP & $94.56 \%$ & $0.00 \%$ & $1.54 \%$ & $3.90 \%$ \\
& PNW & $89.81 \%$ & $0.00 \%$ & $2.50 \%$ & $7.68 \%$ \\
& PSW & $84.18 \%$ & $0.00 \%$ & $3.64 \%$ & $12.18 \%$ \\
& RM & $88.62 \%$ & $0.00 \%$ & $1.98 \%$ & $9.40 \%$ \\
& Total & $92.55 \%$ & $0.00 \%$ & $4.04 \%$ & $3.41 \%$ \\
\hline
\end{tabular}

For climate data, we used county-level weather station data. In order to prepare the data, we proceeded as follows. First, we obtained weather station data from the United States Historical Climatology Network (USHCN) [47] and extracted monthly maximum and minimum temperatures (in ${ }^{\circ} \mathrm{C}$ ) and monthly precipitation (in $\mathrm{mm}$ ) for the years from 1995 to 2017. Then, we computed county-level measures of the following: (a) for counties with multiple stations, we took the average; (b) for counties with only one station, we used data for that station; and (c) for counties without a station, we linearly interpolated values from neighboring counties using ArcGIS. Moreover, in order to use data more representative of long-term climate rather than short-term weather, we computed 3-year moving averages by using data for the three years preceding each census year. Note that in our estimating equation we also included squared terms for the climate variables, allowing the equation to incorporate nonlinear climate effects on livestock mix and allowing identification of potential critical thresholds.

For economic factors, we used county-level measures of species product sale possibilities. For the cow-calf operations, we used the average calf sale value which we derived by dividing total sales revenue by the number of calves sold in order to obtain the average calf sale value. For dairy cows, we multiplied the milk price by reported milk yield per cow in order to obtain the average milk revenue per dairy cow. For goats, we divided sales revenue by the number of animals sold. For sheep, we calculated the wool sales per animal by multiplying wool price by wool production per animal and then added in the average lamb sales revenue per ewe. The data for this were drawn from the Census of Agriculture [46] and the Animal Products database of the USDA Economic Research Service (ERS) [48].

Variables descriptive of regional geographic conditions that we used included the amount of land classified as grassland in a county and a regional fixed effect dummy for the market regions shown above. Grassland available is used as a proxy of the resource base available for raising livestock. Regional dummies for 10 market regions are used to control for systematic regional fixed effects. Year dummies for 5 census years are used to control for year-specific effects.

Table 4 summarizes the descriptive statistics for the explanatory variables. Table 5 presents core explanatory variables values by region. There, we observe that Western US had less precipitation and a wider temperature range. We also observe that the sales value of livestock does not vary much across regions. However, the western region has much larger grassland endowments. 
Table 4. Descriptive statistics.

\begin{tabular}{cccccccc}
\hline Variable & Explanation & Unit & $\mathbf{N}$ & Mean & St. Dev. & Min & Max \\
\hline annual_prcp & & $100 \mathrm{~mm}$ & 15,240 & 9.81 & 3.48 & 0.80 & 24.68 \\
annual_tmax & 3-year moving average of & ${ }^{\circ} \mathrm{C}$ & 15,240 & 26.70 & 3.42 & 17.57 & 36.52 \\
annual_tmin & annual temperature and & ${ }^{\circ} \mathrm{C}$ & 15,240 & -0.95 & 4.93 & -14.38 & 15.26 \\
annual_prcpsq & precipitation and their squares & ${ }^{\circ} \mathrm{C}^{2}$ & 15,240 & 108.76 & 65.52 & 0.64 & 609.16 \\
annual_tmaxsq & ${ }^{\circ} \mathrm{C}^{2}$ & 15,240 & 724.34 & 180.05 & 308.83 & 1334.03 \\
annual_tminsq & & $10,000 \mathrm{~mm}^{2}$ & 15,240 & 25.18 & 31.67 & 0.00 & 233.00 \\
\hline Value_beefcow & & USD & 15,240 & 678.97 & 246.35 & 152.12 & 2080.00 \\
Value_dairycow & The market value per unit of & USD & 15,240 & 2927.30 & 811.09 & 1602.22 & 4875.65 \\
Value_goat & livestock & USD & 15,240 & 132.04 & 25.62 & 6.91 & 891.35 \\
Value_sheep & & USD & 15,240 & 161.60 & 30.83 & 56.29 & 1816.87 \\
\hline Grassland & Grassland available & 1000 acres & 15,240 & 151.69 & 335.25 & 0.02 & 6151.50 \\
\hline Region & Regional dummies & NA & 15,240 & NA & NA & 0.00 \\
\hline Year & Year dummies & NA & 15,240 & NA & NA & 0.00 & 1.00 \\
\hline
\end{tabular}

Table 5. Explanatory variables values by region.

\begin{tabular}{ccccccccccccc}
\hline & \multicolumn{1}{c}{ East } \\
\hline Variable & CB & LS & NE & SC & SE & Total & GP & PNW & PSW & RM & SW & Total \\
\hline annual_prcp & 10.38 & 8.35 & 11.48 & 13.48 & 12.37 & 11.54 & 6.41 & 9.81 & 6.15 & 3.71 & 8.39 & 6.55 \\
annual_tmax & 25.39 & 21.3 & 24.09 & 28.58 & 28.88 & 26.33 & 26.03 & 22.59 & 28.77 & 25.09 & 31.49 & 27.4 \\
annual_tmin & -2.86 & -6.93 & -3.11 & 2.38 & 3.73 & -0.53 & -5.82 & -1.12 & 3.89 & -5.36 & 3.86 & -1.81 \\
Value_cattle & 7.7 & 7.32 & 6.04 & 5.68 & 5.52 & 6.4 & 8.86 & 7 & 6.97 & 7.13 & 6.82 & 7.53 \\
Value_milkcow & 28.77 & 31.37 & 29.58 & 23.68 & 31.31 & 28.52 & 29.1 & 33.67 & 31.41 & 32.03 & 30.33 & 30.7 \\
Value_goat & 1.38 & 1.46 & 1.43 & 1.19 & 1.23 & 1.31 & 1.33 & 1.44 & 1.53 & 1.34 & 1.28 & 1.34 \\
Value_sheep & 1.64 & 1.66 & 1.68 & 1.47 & 1.57 & 1.59 & 1.69 & 1.76 & 1.89 & 1.74 & 1.52 & 1.66 \\
Grassland & 3.58 & 2.12 & 1.72 & 4.31 & 2.92 & 3.16 & 23.60 & 23.39 & 26.47 & 63.66 & 36.94 & 38.37 \\
\hline
\end{tabular}

\section{Results}

\subsection{Livestock Species Mix}

Since we assume that the dairy cows in the east predominantly use grazing land while those in the west are generally kept in confined conditions, we conducted estimations for the east and west separately. The results where beef cows are the baseline species are presented in the Appendix A. The coefficients reported there provide the effects on the $\log$ of the land share for each species relative to that for beef cows. Computed average marginal effects are provided in Tables 6 and 7.

Table 6. Average marginal effects on land share in Eastern US.

\begin{tabular}{ccccc}
\hline VARIABLES & Beef Cows & Dairy Cows & Goats & Sheep \\
\hline annual_tmax & $-0.0729^{* * *}$ & $0.0639^{* * *}$ & $-0.0471^{* * *}$ & $0.0562^{* * *}$ \\
& $(0.0265)$ & $(0.0238)$ & $(0.0102)$ & $(0.0090)$ \\
annual_tmaxsq & $0.0031^{* * *}$ & $-0.0025^{* * *}$ & $0.0008^{* * *}$ & $-0.0014^{* * *}$ \\
& $(0.0005)$ & $(0.0005)$ & $(0.0002)$ & $(0.0002)$ \\
annual_tmin & $-0.0428^{* * *}$ & $0.0286^{* * *}$ & $0.0059^{* * *}$ & $0.0083^{* * *}$ \\
& $(0.0020)$ & $(0.0018)$ & $(0.0011)$ & $(0.0009)$ \\
annual_tminsq & -0.0001 & 0.0001 & $-0.0002^{* * *}$ & $0.0003^{* * *}$ \\
& $(0.0002)$ & $(0.0002)$ & $(0.0001)$ & $(0.0001)$ \\
annual_prcp & $-0.0807^{* * *}$ & $0.0500^{* * *}$ & $0.0249^{* * *}$ & 0.0059 \\
& $(0.0119)$ & $(0.0114)$ & $(0.0056)$ & $(0.0040)$ \\
annual_prcpsq & $0.0040^{* * *}$ & $-0.0028^{* * *}$ & $-0.0010^{* * *}$ & -0.0002 \\
& $(0.0005)$ & $(0.0005)$ & $(0.0002)$ & $(0.0002)$ \\
\hline
\end{tabular}


Table 6. Cont.

\begin{tabular}{|c|c|c|c|c|}
\hline VARIABLES & Beef Cows & Dairy Cows & Goats & Sheep \\
\hline Value_beefcow & $\begin{array}{c}0.0110^{* * *} \\
(0.0016)\end{array}$ & $\begin{array}{c}-0.0182 * * * \\
(0.0015)\end{array}$ & $\begin{array}{c}0.0023 * * * \\
(0.0006)\end{array}$ & $\begin{array}{c}0.0048^{* * * *} \\
(0.0005)\end{array}$ \\
\hline Value_milkcow & $\begin{array}{c}-0.0110^{* * *} \\
(0.0008)\end{array}$ & $\begin{array}{c}0.0131 * * * \\
(0.0007)\end{array}$ & $\begin{array}{c}-0.0008^{* *} \\
(0.0004)\end{array}$ & $\begin{aligned}-0.0013^{* * *} & (0.0003)\end{aligned}$ \\
\hline Value_goat & $\begin{array}{c}-0.0264 * * * \\
(0.0091)\end{array}$ & $\begin{array}{c}0.0204^{* * *} \\
(0.0075)\end{array}$ & $\begin{array}{c}0.0050 \\
(0.0032)\end{array}$ & $\begin{array}{c}0.0009 \\
(0.0022)\end{array}$ \\
\hline Value_sheep & $\begin{array}{c}-0.0387^{* * *} \\
(0.0073)\end{array}$ & $\begin{array}{c}0.0245^{* * *} \\
(0.0064)\end{array}$ & $\begin{array}{c}0.0025 \\
(0.0027)\end{array}$ & $\begin{array}{c}0.0116^{* * * *} \\
(0.0020)\end{array}$ \\
\hline Grassland & $\begin{array}{c}0.0487^{* * * *} \\
(0.0117)\end{array}$ & $\begin{array}{c}0.0248^{* * *} \\
(0.0061)\end{array}$ & $\begin{array}{c}-0.0449^{* * * *} \\
(0.0087)\end{array}$ & $\begin{aligned} &-0.0285 * * * \\
&(0.0087)\end{aligned}$ \\
\hline Region $=$ LS & $\begin{array}{c}-0.0912 * * * \\
(0.0110)\end{array}$ & $\begin{array}{c}0.0859^{* * *} \\
(0.0112)\end{array}$ & $\begin{array}{c}0.0010 \\
(0.0028)\end{array}$ & $\begin{array}{l}0.0044 * \\
(0.0026)\end{array}$ \\
\hline Region $=$ NE & $\begin{array}{c}-0.1327^{* * *} \\
(0.0081)\end{array}$ & $\begin{array}{c}0.0989^{* * * *} \\
(0.0082)\end{array}$ & $\begin{array}{c}0.0136^{* * *} \\
(0.0026)\end{array}$ & $\begin{array}{c}0.0201 * * * \\
(0.0024)\end{array}$ \\
\hline Region $=$ SC & $\begin{array}{c}0.0476^{* * *} \\
(0.0082)\end{array}$ & $\begin{array}{c}-0.0455^{* * *} \\
(0.0074)\end{array}$ & $\begin{array}{c}0.0030 \\
(0.0029)\end{array}$ & $\begin{array}{l}-0.0052 \\
(0.0036)\end{array}$ \\
\hline Region $=$ SE & $\begin{array}{c}0.0395^{* * *} \\
(0.0093)\end{array}$ & $\begin{array}{c}-0.0827^{* * *} \\
(0.0066)\end{array}$ & $\begin{array}{c}0.0227^{* * *} \\
(0.0043)\end{array}$ & $\begin{array}{c}0.0205^{* * *} \\
(0.0060)\end{array}$ \\
\hline Year $=2002$ & $\begin{array}{c}0.0388^{* * *} \\
(0.0076)\end{array}$ & $\begin{array}{c}-0.0358^{* * *} \\
(0.0075)\end{array}$ & $\begin{array}{l}-0.0040 \\
(0.0034)\end{array}$ & $\begin{array}{c}0.0009 \\
(0.0028)\end{array}$ \\
\hline Year $=2007$ & $\begin{array}{c}0.0825^{* * *} \\
(0.0100)\end{array}$ & $\begin{array}{c}-0.0783^{* * *} \\
(0.0101)\end{array}$ & $\begin{array}{l}-0.0002 \\
(0.0042)\end{array}$ & $\begin{array}{l}-0.0040 \\
(0.0037)\end{array}$ \\
\hline Year $=2012$ & $\begin{array}{c}0.1315^{* * *} \\
(0.0138)\end{array}$ & $\begin{array}{c}-0.1235^{* * *} \\
(0.0137)\end{array}$ & $\begin{array}{l}-0.0039 \\
(0.0058)\end{array}$ & $\begin{array}{l}-0.0041 \\
(0.0053)\end{array}$ \\
\hline Year $=2017$ & $\begin{array}{c}0.2059^{* * *} \\
(0.0148)\end{array}$ & $\begin{array}{c}-0.2051^{* * *} \\
(0.0136)\end{array}$ & $\begin{array}{c}0.0010 \\
(0.0073)\end{array}$ & $\begin{array}{l}-0.0017 \\
(0.0061)\end{array}$ \\
\hline Observations & 9941 & 9941 & 9941 & 9941 \\
\hline
\end{tabular}

Note: (1) Average marginal effects are calculated from coefficients of multinomial logit model. (2) Heteroskedasticity-consistent robust standard errors [42] in parentheses. (3) ${ }^{* * *} p<0.01,{ }^{* *} p<0.05, * p<0.1$.

Table 7. Average marginal effect on land share in Western US.

\begin{tabular}{cccc}
\hline VARIABLES & Beef Cows & Goats & Sheep \\
\hline annual_tmax & $0.0952^{* * *}$ & $-0.0159^{* * * *}$ & $-0.0794^{* * *}$ \\
& $(0.0113)$ & $(0.0049)$ & $(0.0086)$ \\
annual_tmaxsq & $-0.0018^{* * *}$ & $0.0003^{* * *}$ & $0.0015^{* * *}$ \\
& $(0.0002)$ & $(0.0001)$ & $(0.0002)$ \\
annual_tmin & $-0.0029^{* *}$ & $0.0017^{* * *}$ & 0.0012 \\
& $(0.0015)$ & $(0.0007)$ & $(0.0010)$ \\
annual_tminsq & $0.0009^{* * *}$ & $-0.0005^{* * *}$ & $-0.0004^{* * *}$ \\
& $(0.0001)$ & $(0.0001)$ & $(0.0001)$ \\
annual_prcp & $0.0185^{* * *}$ & $-0.0063^{* * * *}$ & $-0.0122^{* * *}$ \\
& $(0.0029)$ & $(0.0015)$ & $(0.0020)$ \\
annual_prcpsq & $-0.0006^{* * *}$ & $0.0002^{* * *}$ & $0.0004^{* * *}$ \\
& $(0.0001)$ & $(0.0001)$ & $(0.0001)$ \\
Value_beefcow & $-0.0034^{*}$ & 0.0001 & $0.0033^{* *}$ \\
& $(0.0018)$ & $(0.0009)$ & $-0.0013)$ \\
Value_goat & $0.0231^{* *}$ & -0.0045 & $(0.0076)$ \\
Value_sheep & $(0.0101)$ & $(0.0044)$ & $0.0064^{* *}$ \\
& -0.0029 & -0.0034 & $(0.0030)$ \\
Grassland & $(0.0064)$ & $(0.0053)$ & $0.0010^{* * *}$ \\
Region = PNW & -0.0006 & $-0.0004^{* *}$ & $(0.0002)$ \\
Region = PSW & $(0.0004)$ & $(0.0002)$ & 0.0107 \\
& -0.0146 & 0.0039 & $(0.0100)$ \\
& $(0.0142)$ & $(0.0080)$ & $0.0653^{* * *}$ \\
& $-0.0619^{* * *}$ & -0.0034 & $(0.0159)$ \\
\hline
\end{tabular}


Table 7. Cont.

\begin{tabular}{cccc}
\hline VARIABLES & Beef Cows & Goats & Sheep \\
\hline Region $=$ RM & $-0.0201^{*}$ & -0.0080 & $0.0281^{* * *}$ \\
& $(0.0106)$ & $(0.0060)$ & $(0.0077)$ \\
Region $=$ SW & $0.0296^{* * *}$ & -0.0039 & $-0.0257^{* * *}$ \\
& $(0.0100)$ & $(0.0066)$ & $(0.0061)$ \\
Year $=2002$ & $0.0242^{* *}$ & -0.0046 & $-0.0196^{* * *}$ \\
& $(0.0095)$ & $(0.0041)$ & $(0.0074)$ \\
Year $=2007$ & $0.0275^{* * *}$ & -0.0012 & $-0.0263^{* * *}$ \\
& $(0.0105)$ & $(0.0047)$ & $(0.0082)$ \\
Year = 2012 & $0.0510^{* * *}$ & -0.0070 & $-0.0440^{* * *}$ \\
& $(0.0125)$ & $(0.0057)$ & $(0.0096)$ \\
Year = 2017 & $0.0360^{* * *}$ & 0.0005 & $-0.0365^{* * *}$ \\
& $(0.0129)$ & $(0.0059)$ & $(0.0098)$ \\
Observations & 5268 & 5268 & 5268
\end{tabular}

Note: (1) Average marginal effects are calculated from coefficients of multinomial logit model. (2) Heteroskedasticity-consistent robust standard errors [42] in parentheses. (3) ${ }^{* * *} p<0.01,{ }^{* *} p<0.05, * p<0.1$.

The coefficients here provide the effects on land share for each species. The results show that most explanatory variables exert significant effects and that all four species exhibit nonlinear relationships with at least one climate variable, which confirms Hypothesis 1.

Figures 2 and 3 show graphs of the estimated relationship for each species that relate the grazing land share with climate variables, holding all other variables at their mean level. Since beef cows have larger land shares, a secondary $y$-axis for beef cows is displayed on the right.

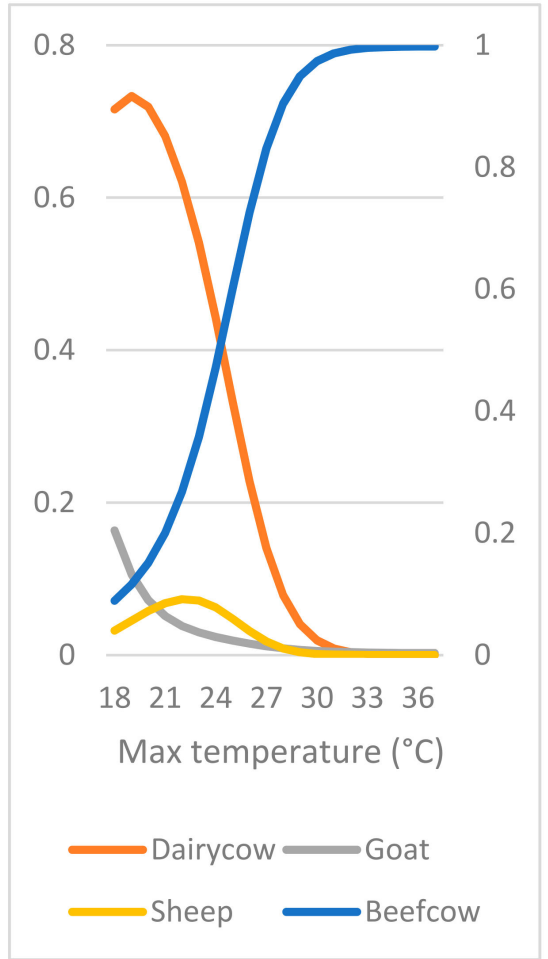

(a)

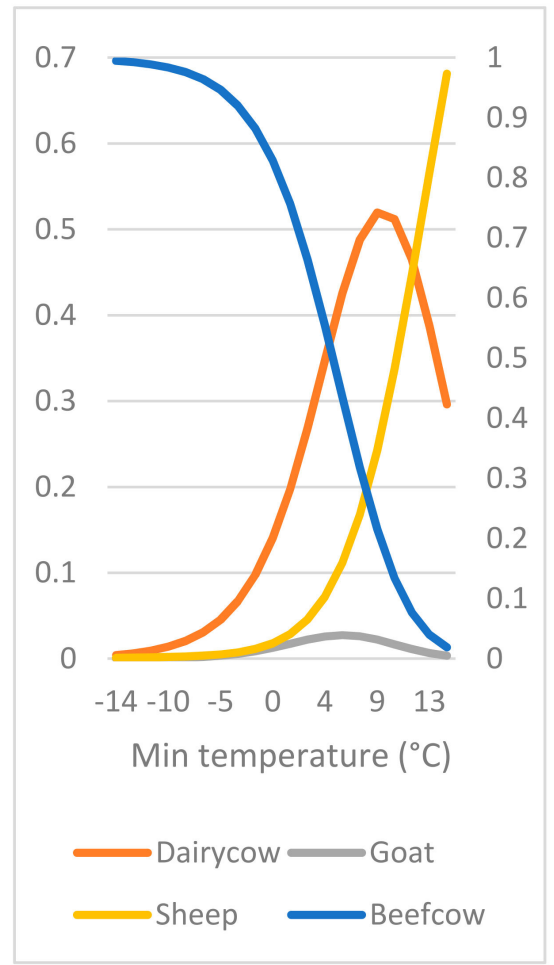

(b)

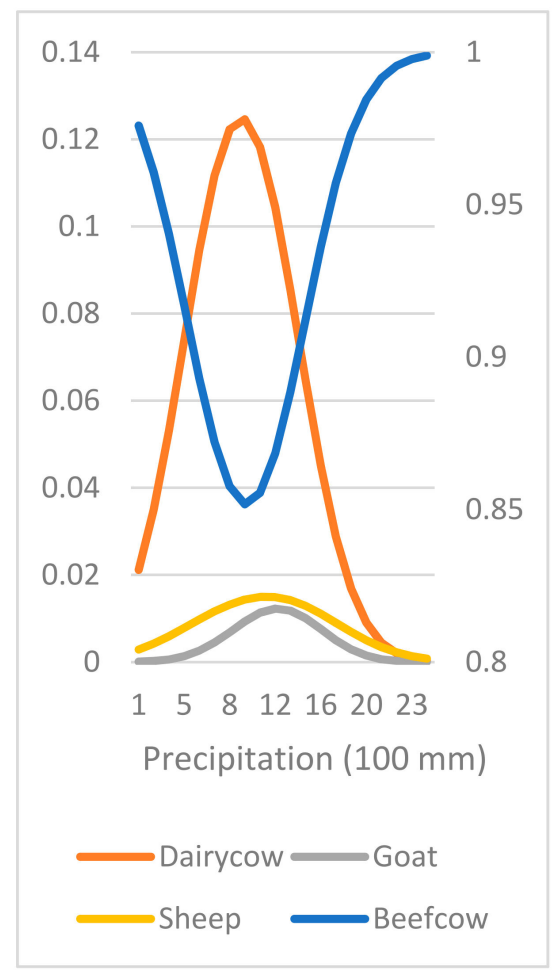

(c)

Figure 2. Average marginal effect of climate variables on land shares in the east: (a) Maximum Temperature; (b) Minimum Temperature; (c) Precipitation. 


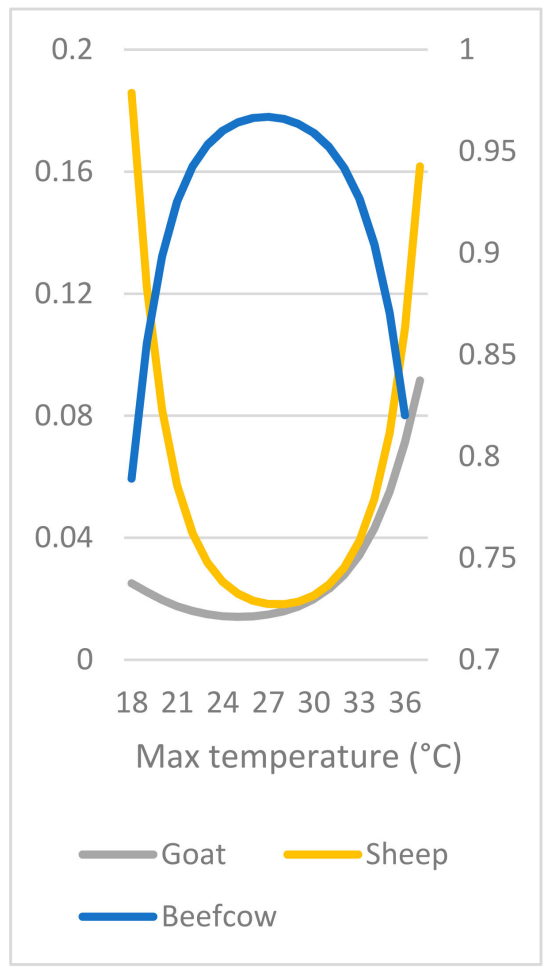

(a)

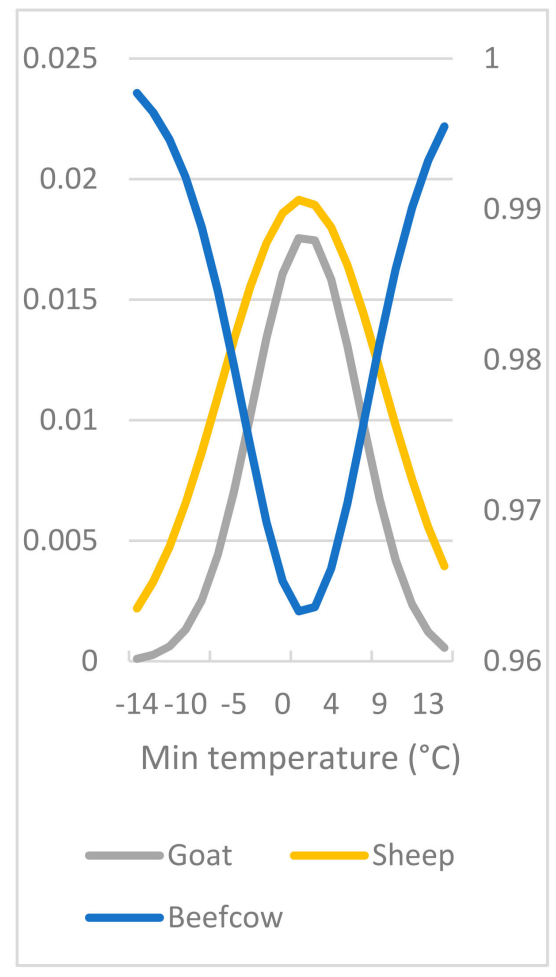

(b)

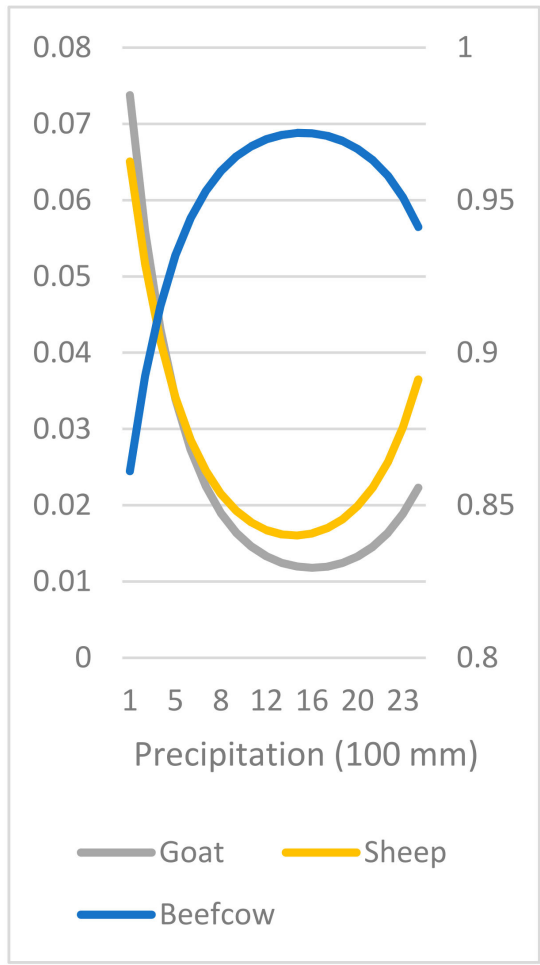

(c)

Figure 3. Average marginal effect of climate variables on land shares in the west: (a) Maximum Temperature; (b) Minimum Temperature; (c) Precipitation.

We first examine average marginal land share effects in Eastern US. There, we find maximum temperature exerts positive effects on beef cow land share and negative effects on dairy cow and goat land shares, indicating a potential substitution between beef and dairy cows/goats. The beef cow share approaches one when the annual maximum temperature reaches high levels, and dairy cow and goat shares increase when the annual maximum temperature falls to low levels. Sheep display inverse $U$ shape curves with their land share increasing from low temperature levels and then peaking at $22{ }^{\circ} \mathrm{C}$ and decreasing from thereon. This shows differential responses by species verifying Hypothesis 2.

For annual minimum temperature, we observe smaller beef cow land shares as the minimum becomes higher. Unlike beef cows, the sheep land share increases as the minimum temperature increases. An inverse U-shape land share curve is found for dairy cows and goats peaking at $9{ }^{\circ} \mathrm{C}$ and $6{ }^{\circ} \mathrm{C}$, respectively. By examining the maximum and minimum temperature figures together, we find that the optimal temperature ranges for dairy cows and sheep are rather narrow. The land shares of dairy cows and sheep are larger under simultaneous high minimum and relatively low maximum temperature, but at extreme temperatures, almost all lands switch to beef cows. Goats exhibit flatter curves and maintain stable proportions as the minimum temperature changes, showing that goats are less sensitive to temperature. Again, Hypothesis 2 is confirmed here.

With respect to precipitation, we find a U-shape beef cow land share curve with an inflection point of $1000 \mathrm{~mm}$ with the share increasing when the precipitation rises or falls from that. All other species display inverse $U$ shape curves with dairy cow land shares peaking at $900 \mathrm{~mm}$, sheep land shares peaking at $1100 \mathrm{~mm}$, and goat shares peaking at $1200 \mathrm{~mm}$. We find that in the east, dairy cows substitute for beef cows as they have almost opposite curves. Moreover, we observed that dairy cow shares increase in warm regions with relatively high minimum temperature but decrease in cold regions with low minimum temperature or hot regions with high maximum temperature. The land share of beef cows 
approaches one when the minimum temperature drops and the maximum temperature rises, reflecting the higher range of tolerance of beef animals.

Figure 3 shows land shares for beef cows, goats, and sheep in the western US (as explained above grazing dairy cows are not included there). Here, we see different effects on land shares compared to the east. Namely, Figure 3a shows that beef cow shares demonstrate an inverse $U$ shape relationship with the maximum temperature peaking at $25^{\circ} \mathrm{C}$ and beef cow shares decreasing afterward. The opposite is found for goats and sheep with the threshold of around $25^{\circ} \mathrm{C}$ and $27^{\circ} \mathrm{C}$, respectively, with the curve for goats being flatter. With respect to annual minimum temperature, we find a $U$ shape curve for beef cow shares and inverse $U$ shape curves for goat and sheep shares with the inflection point for annual minimum temperature being $2{ }^{\circ} \mathrm{C}$ The effect of precipitation shows a similar pattern. An inverse $\mathrm{U}$ shape curve is found for beef cow shares peaking at $1500 \mathrm{~mm}$ while U shape curves are observed for goats and sheep shares with inflection points of $1600 \mathrm{~mm}$ and $1400 \mathrm{~mm}$. Thus, beef cow shares display opposite curves to other species, signifying substitution effects between beef cows and the other species.

In terms of sales value, in the east, the land share of beef cows is positively impacted by the calf sales price but is negatively impacted by the sales market values for other species. For dairy cows, we observe a positive response to milk, goat, and sheep sales value but a negative response to that for beef cows again, showing a land share substitution relationship between beef and dairy cows. Both goats and sheep shares react positively to beef sales value but negatively to milk sales value. Goat shares are not significantly affected by their own market value while sheep are positively correlated with theirs. In the west, beef cow shares are negatively affected by calf sales value but positively by goat sales value. We also observed that sheep shares are sensitive to market values but goat shares are not. To be specific, sheep react positively to sheep and beef cow sales value but negatively to that of goats. Goats are not significantly affected by the market value.

The amount of grassland in a county has a positive impact on the land share of beef and dairy cows in the east but no significant effect in the west. The possible reason for this is that grassland in the east is more valuable [49], and farmers tend to increase cow land shares when grassland is abundant. According to the report of Land Values 2021 Summary released by USDA NASS [49], grassland in the east is valued at USD 2993 per acre while that in the west is valued at USD 1209 per acre. In the east, both sheep and goat shares react negatively to grassland amount, showing that sheep and goats are more likely to be raised in counties with smaller grassland availability. In the west, goats are not significantly affected by grassland availability while sheep are positively impacted.

Most regional dummies are highly significant, suggesting the existence of regionspecific effects. In terms of year-specific effects, we observe an increasing share of beef cows since the time dummy coefficients are positive and increasing as we move to more recent years. The coefficients for dairy cow shares decrease with a similar magnitude, demonstrating shrinking land shares over time perhaps due to industry trends toward larger animals with greater milk yields and an assumption of constant AUM requirements. Sheep and goat shares exhibit less unique year-specific effects due to the insignificance of coefficients.

\subsection{Climate Scenarios}

We projected the effects of climate change on grazing livestock land shares by decades using projections from the Coupled Model Intercomparison Project Phase 5 (CMIP5) [50]. We use four Representative Concentration Pathways (RCPs) to reflect different degrees of climate change mitigation: RCP 2.6, RCP 4.5, RCP 6.0, and RCP 8.5. As explained in IPCC [1], RCP 2.6 scenario implies the least future warming, and RCP 8.5 implied the most.

We obtained the projected temperature and precipitation by averaging gridded data from six different climate models following Cho and McCarl [18]: CanESM2, CCSM4, CESM1-CAM5, GFDL-CM3, HadGEM2-ES, and MPI-ESM-MR. The specific projections were obtained from the Technical Service Center, US Bureau of Reclamation [50]. We calcu- 
lated county-level climate data by averaging grid-point values. All climate scenarios exhibit increasing temperature and precipitation (Figure 4 ). Temperature does not differ very much among RCPs between now and 2050, whereas there is about a $4{ }^{\circ} \mathrm{C}$ discrepancy between RCP 8.5 and RCP 2.6 by 2090. The rainfall predictions are more variable. In general, the greater the radiative forcing, the higher the temperature, and the more the precipitation.
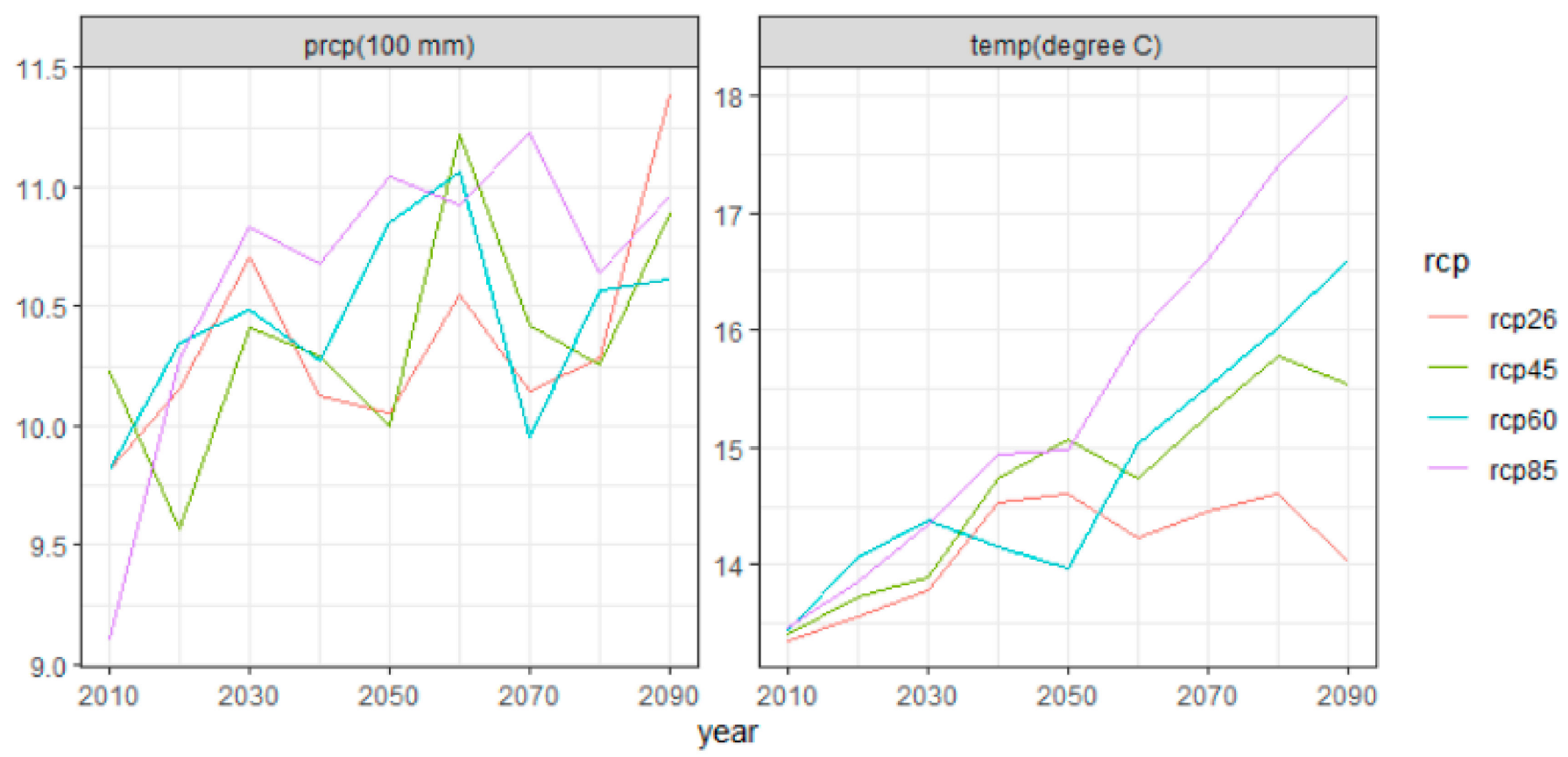

Figure 4. Projected temperature and precipitation by 2090 under climate scenarios.

Since we focus on climate effects, we keep economic and fixed effect variables fixed at their 2017 level so that the projections only reflect the marginal effects of climate change and grassland change. Grassland change is projected from FASOMGHG [38]. Figure 5 shows the impacts of these climate scenarios on species land use shares. The baseline is 2020. Here, we observed that dairy and beef cow shares experience substantial changes in opposite directions under all four RCP scenarios with the size of the shifts increasing as the radiative forcing is larger. Under RCP 8.5, the 2090 share for beef cows increases by $9 \%$, while that for dairy cows decreases by $8 \%$. The goat land share shows a downward trend, and the sheep land share increases under all scenarios with RCP 8.5 displaying the greatest changes.

Figure 6 shows regional changes in land shares under RCP 8.5 for 2090 and illustrates results relevant to Hypothesis 3 . Note that in the projection dairy cows share effects are only present east of the Mississippi River. We observed significant regional similarities in the effects for all species. For example, the most significant increase in beef cow shares primarily occurs in Northwestern US with a few counties exhibiting shares proceeding up to more than 50\%. Beef cow land shares in Central and Northeastern US are stable, varying within a $5 \%$ range. Dairy cows exhibit a declining land proportion almost everywhere except for counties in the lake states and the northeast. The land share changes of goats are minimal, with most counties adjusting within a $5 \%$ range. However, goat shares in the lake states and northeast region decrease significantly due to substitution with dairy cows. Mixed effects occur for sheep land shares, with decreases in most western counties and increases in Eastern US. Sheep shares decrease significantly in the northwest with beef cows increasing. 


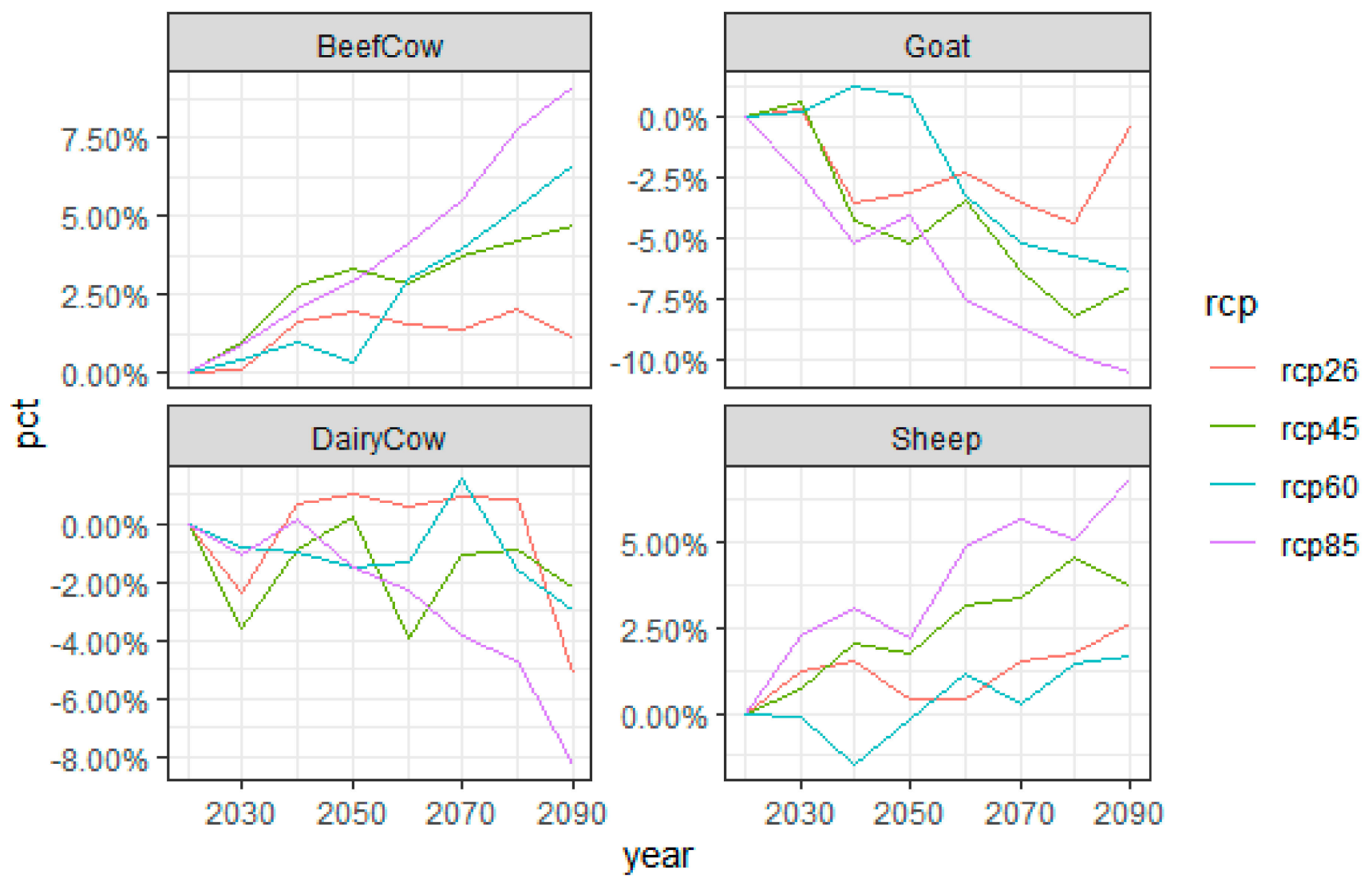

Figure 5. Projected land share change of livestock by 2090 relative to 2020 under climate scenarios.

a. Regional Change of Land Share of Beef Cows

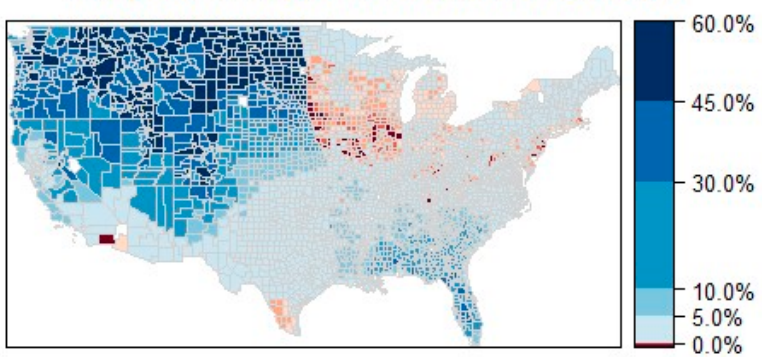

c. Regional Change of Land Share of Goats

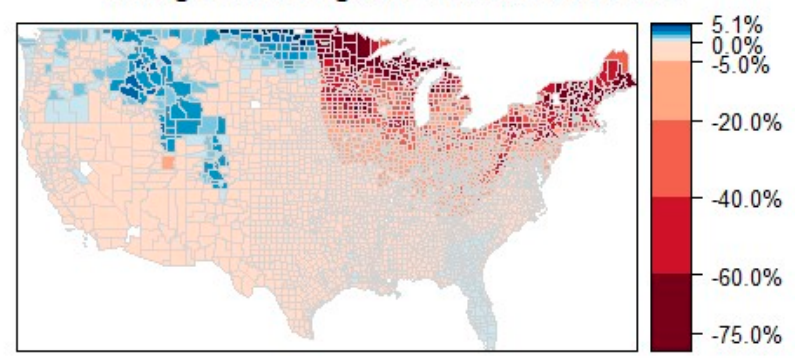

b. Regional Change of Land Share of Dairy Cows

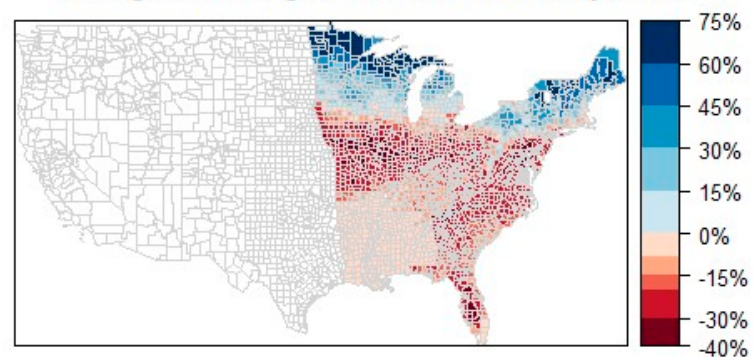

d. Regional Change of Land Share of Sheep

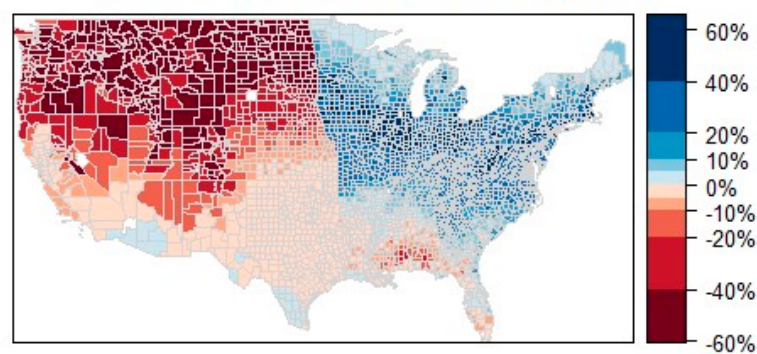

Figure 6. Regional change of land share of livestock in 2090 relative to 2020 under RCP 8.5: (a) Beef cows; (b) Dairy cows; (c) Goats; (d) Sheep.

\section{Conclusions}

This study explores how farmers adapt grazing livestock species land use shares to climate. We estimate a fractional multinomial logit econometric model to examine this 
for dairy cows, beef cows, goats, and sheep. Dairy cows were only considered in the east because they are mostly raised in confinement in the west. The data show that beef cows are dominant in most counties with many land shares close to one. Meanwhile, goats and sheep typically have relatively small shares. A multinomial fractional logit is utilized for the estimation because it is able to deal with a data set with a nontrivial frequency of boundary values ( 0 and 1$)$ and is free of the independence of irrelevant alternatives (IIA) problem.

We find in eastern US regions that dairy cow and sheep land shares increase under mild weather conditions with relatively high minimum temperatures, low maximum temperatures, and moderate precipitation. At extreme conditions we find beef cow shares increase often with land shares approaching one. In Western US, the beef cow shares display a nonlinear relationship with climate variables with land shares for goats and sheep substituting for land share with beef cows. Goats exhibit flatter curves in both the east and the west. Precipitation also has substantial effects on the east and west land shares of all species. We find beef cows demonstrate a U-shape curve east of the Mississippi River and an inverse U-shape curve in the west with all other species reacting oppositely.

We simulate future livestock share shifts under RCP 2.6, RCP 4.5, RCP 6.0, and RCP 8.5. The results under all four RCP scenarios exhibit similar patterns with the shifts being largest under the highest-emission scenario (RCP 8.5). The most significant change occurs with cow land use shares. The results generally show increasing shares for beef cows with that in Northwestern US increasing the most. We also observe decreasing dairy cow shares except in the lake states and northeast. Goat land use shares exhibit small shifts in most of the US except for the lake states and northeast where they are substituted with dairy cows. Sheep land use shares show spatial clustering effects with decreasing land share primarily observed in the west and increasing land share in the east.

As previous US studies focused on crops or the transition from cropland to grassland, there are no comparable US studies. However, our results can be compared with studies in South America [29], Africa [19], and Australia [33,34]. Our results are consistent with Australian studies where we both find increases in beef cows and sheep along with decreases in dairy cows. Studies in South America and Africa also found fewer dairy cows and a greater percentage of sheep and goats but a smaller share of beef cows in contrast with our findings.

There are some likely reasons for the difference in findings. First, livestock management differs. Our study considers only grazing animals while other studies include confined animals that usually are less affected by climate change because confinement allows more control over climate exposure with confined pigs and chickens increasing. Second, geography and local climate patterns play a role, with substantial portions of Africa and South America in the tropic exhibiting higher temperatures and more varied precipitation. Cattle there may suffer from greater heat stress, forcing farmers to switch to more heat-tolerant species such as sheep and goats. On the other hand, Australia and US exhibit more land in temperate zones, which may favor the cattle industry. Third, we believe that the composition of livestock species and local food preferences causes some differences as well. For example, goats account for less than $1 \%$ of livestock product values in the US, but Africa contributes $35.7 \%$ of world production, suggesting preference differences for goats and goat products. On the other hand, the beef cattle industry is the largest livestock sector in the US, with high expected profit and various breeds. Fourth, adaptation through changing breeds may be a force but we do not have data to examine that [17].

Taking these considerations together, we do find that land shares of livestock species have a nonlinear relationship with climate. Extreme climate conditions reduce livestock performance; therefore, farmers adapt by changing land use shares. Note that dairy cows are relatively vulnerable to climate change among the species we considered. The vulnerability of dairy cows should be noted by policymakers as the dairy industry contributed around $20 \%$ of livestock values. 
There are several limitations to this study. First, we only explored the spatial variation of data by including year-fixed effects because only five census years were available (four for goats). Therefore, an extension would be to use more available data over a longer period of time. Second, we have performed some weather and inventory data interpolation by using values from nearby counties or other years and also some aggregation over livestock sales values. More complete data would be desirable. Third, we tried to include control variables on product sales values and geographic characteristics to estimate other systematic factors behind livestock land use share shifts but there might be important omitted variables such as carbon dioxide concentration, livestock production costs, and region-specific agricultural policies that could improve our ability to explain the shifts. For example, increased concentration of carbon dioxide may boost pasture yield or alter grass quality and partially offset the adverse effects of climate change.

Author Contributions: Conceptualization, B.A.M.; Data curation, M.W.; Formal analysis, M.W. and B.A.M.; Methodology, M.W. and B.A.M.; Software, M.W.; Validation, B.A.M.; Writing-original draft, M.W.; Writing - review \& editing, M.W. and B.A.M. All authors have read and agreed to the published version of the manuscript.

Funding: This research was funded by the Fundamental Research Funds for the Central Universities (Grant no. JBK2101049).

Institutional Review Board Statement: Not applicable.

Informed Consent Statement: Not applicable.

Data Availability Statement: The data presented in this study are openly available in USDA Quick Stats at https:/ / quickstats.nass.usda.gov [46] (accessed on 17 November 2021), USHCN at https:/ / www.ncei.noaa.gov/products/land-based-station/us-historical-climatology-network [47] (accessed on 17 November 2021), USDA ERS at https:/ /www.ers.usda.gov/data-products/milkcost-of-production-estimates / [48] (accessed on 17 November 2021), and Downscaled CMIP3 and CMIP5 climate projections at ftp://gdo-dcp.ucllnl.org/pub/dcp/archive/cmip5/bcsd [50] (accessed on 17 November 2021).

Conflicts of Interest: The authors declare no conflict of interest.

\section{Appendix A}

Table A1. Estimation results for livestock land use share in the east.

\begin{tabular}{cccc}
\hline VARIABLES & Dairy Cows & Goats & Sheep \\
\hline annual_tmax & $0.6183^{* * *}$ & $-1.3994^{* * * *}$ & $1.8614^{* * *}$ \\
& $(0.2014)$ & $(0.3438)$ & $(0.2810)$ \\
annual_tmaxsq & $-0.0238^{* * *}$ & $0.0194^{* * *}$ & $-0.0493^{* * *}$ \\
& $(0.0040)$ & $(0.0069)$ & $(0.0058)$ \\
annual_tmin & $0.2782^{* * *}$ & $0.2702^{* * *}$ & $0.3547^{* * *}$ \\
& $(0.0147)$ & $(0.0371)$ & $(0.0270)$ \\
annual_tminsq & $0.0010^{* * *}$ & $-0.0077^{* * *}$ & $0.0086^{* * *}$ \\
& $(0.0013)$ & $(0.0026)$ & $(0.0019)$ \\
annual_prcp & $0.4886^{* * *}$ & $0.9598^{* * * *}$ & $0.3736^{* * *}$ \\
& $(0.0947)$ & $(0.1903)$ & $(0.1224)$ \\
annual_prcpsq & $-0.0261^{* * *}$ & $-0.0396^{* * * *}$ & $-0.0168^{* * *}$ \\
& $(0.0041)$ & $(0.0077)$ & $(0.0052)$ \\
Value_cattle & $-0.1377^{* * *}$ & $0.0560^{* * *}$ & $0.1060^{* * *}$ \\
& $(0.0128)$ & $(0.0217)$ & $(0.0162)$ \\
Value_milkcow & $0.1070^{* * *}$ & -0.0051 & -0.0070 \\
Value_goat & $(0.0061)$ & $(0.0126)$ & $(0.0094)$ \\
& $0.1862^{* * *}$ & $0.2120^{*}$ & 0.0966 \\
& $(0.0657)$ & $(0.1136)$ & $(0.0775)$ \\
\hline
\end{tabular}


Table A1. Cont.

\begin{tabular}{cccc}
\hline VARIABLES & Dairy Cows & Goats & Sheep \\
\hline Value_sheep & $0.2469^{* * *}$ & 0.1528 & $0.4406^{* * *}$ \\
& $(0.0547)$ & $(0.0958)$ & $(0.0677)$ \\
GrassLand & 0.0500 & $-1.5575^{* * *}$ & $-0.9170^{* * *}$ \\
Region = LS & $(0.0395)$ & $(0.2975)$ & $(0.2736)$ \\
& $0.5977^{* * *}$ & $0.2032^{*}$ & $0.3438^{* * *}$ \\
Region $=$ NE & $(0.0684)$ & $(0.1220)$ & $(0.0824)$ \\
& $0.7395^{* * *}$ & $0.7070^{* * *}$ & $0.8266^{* * *}$ \\
Region $=$ SC & $\left(0.0504^{* * *}\right.$ & $(0.0878)$ & $(0.0603)$ \\
& $-0.3843^{* * *}$ & 0.0447 & $-0.2985^{* *}$ \\
Region $=$ SE & $(0.0608)$ & $(0.1236)$ & $(0.1518)$ \\
& $-0.6774^{* * *}$ & $0.6278^{* * *}$ & $0.4474^{* * *}$ \\
Year $=2002$ & $(0.0608)$ & $(0.1231)$ & $(0.1445)$ \\
Year $=2007$ & $-0.2696^{* * *}$ & $-0.2121^{*}$ & -0.0867 \\
& $(0.0520)$ & $(0.1165)$ & $(0.0844)$ \\
Year $=2012$ & $-0.6154^{* * *}$ & -0.1672 & $-0.3636^{* * *}$ \\
Year $=2017$ & $(0.0719)$ & $(0.1442)$ & $(0.1171)$ \\
& $-1.0237^{* * *}$ & $-0.3843^{*}$ & $-0.5037^{* * *}$ \\
Constant & $(0.1073)$ & $(0.2090)$ & $(0.1709)$ \\
& $-1.9417^{* * *}$ & -0.3564 & $-0.6432^{* * *}$ \\
Observations & $(0.1320)$ & $(0.2485)$ & $(0.1991)$ \\
\hline Note: (1) The base case is beef cows. & $-5.2240^{*}$ & $14.2166^{* * *}$ & $-20.5704^{* * *}$
\end{tabular}

Table A2. Estimation results for on livestock land use share in the west.

\begin{tabular}{|c|c|c|}
\hline VARIABLES & Goats & Sheep \\
\hline annual_tmax & $\begin{array}{c}-0.7557^{* * *} \\
(0.2080)\end{array}$ & $\begin{array}{c}-1.5047^{* * *} \\
(0.1584)\end{array}$ \\
\hline annual_tmaxsq & $\begin{array}{c}0.0153^{* * *} \\
(0.0037)\end{array}$ & $\begin{array}{c}0.0277^{* * *} \\
(0.0032)\end{array}$ \\
\hline annual_tmin & $\begin{array}{l}0.0699 * * \\
(0.0314)\end{array}$ & $\begin{array}{c}0.0253 \\
(0.0195)\end{array}$ \\
\hline annual_tminsq & $\begin{array}{c}-0.0199 * * * \\
(0.0019)\end{array}$ & $\begin{array}{c}-0.0088^{* * *} \\
(0.0015)\end{array}$ \\
\hline annual_prcp & $\begin{array}{c}-0.2730 * * * \\
(0.0590)\end{array}$ & $\begin{array}{c}-0.2359^{* * *} \\
(0.0381)\end{array}$ \\
\hline annual_prcpsq & $\begin{array}{c}0.0086^{* * *} \\
(0.0027)\end{array}$ & $\begin{array}{l}0.0082^{* * *} \\
(0.0017)\end{array}$ \\
\hline Value_cattle & $\begin{array}{c}0.0089 \\
(0.0362)\end{array}$ & $\begin{array}{l}0.0616^{* *} \\
(0.0243)\end{array}$ \\
\hline Value_goat & $\begin{array}{l}-0.2097 \\
(0.1843)\end{array}$ & $\begin{array}{c}-0.3525^{* *} \\
(0.1435)\end{array}$ \\
\hline Value_sheep & $\begin{array}{l}-0.1320 \\
(0.2168)\end{array}$ & $\begin{array}{l}0.1141^{* *} \\
(0.0577)\end{array}$ \\
\hline GrassLand & $\begin{array}{l}-0.0148 \\
(0.0097)\end{array}$ & $\begin{array}{c}0.0180^{* * *} \\
(0.0044)\end{array}$ \\
\hline Region $=$ PNW & $\begin{array}{c}0.1490 \\
(0.2740)\end{array}$ & $\begin{array}{c}0.1975 \\
(0.1775)\end{array}$ \\
\hline Region $=$ PSW & $\begin{array}{l}-0.0287 \\
(0.2985)\end{array}$ & $\begin{array}{l}0.8701^{* * * *} \\
(0.1895)\end{array}$ \\
\hline Region $=\mathrm{RM}$ & $\begin{array}{l}-0.2895 \\
(0.2384)\end{array}$ & $\begin{array}{c}0.4385^{* * *} \\
(0.1278)\end{array}$ \\
\hline Region $=$ SW & $\begin{array}{l}-0.1887 \\
(0.2492)\end{array}$ & $\begin{array}{c}-0.6635^{* * *} \\
(0.1495)\end{array}$ \\
\hline
\end{tabular}


Table A2. Cont.

\begin{tabular}{ccc}
\hline VARIABLES & Goats & Sheep \\
\hline Year $=2002$ & -0.2117 & $-0.2974^{* * *}$ \\
& $(0.1659)$ & $(0.1072)$ \\
Year $=2007$ & -0.0803 & $-0.4100^{* * *}$ \\
& $(0.1803)$ & $(0.1203)$ \\
Year $=2012$ & -0.3573 & $-0.7970^{* * *}$ \\
& $(0.2418)$ & $(0.1619)$ \\
Year $=2017$ & -0.0330 & $-0.6097^{* * *}$ \\
& $(0.2218)$ & $(0.1590)$ \\
Constant & $7.9269^{* *}$ & $18.6982^{* * *}$ \\
& $(3.1065)$ & $(2.0474)$ \\
Observations & 5268 & 5268 \\
\hline Note: (1) The base case is beef cows. (2) Robust standard errors in parentheses. $(3)^{* * *} p<0.01,{ }^{* *} p<0.05,{ }^{*} p<0.1$.
\end{tabular}

\section{References}

1. Masson-Delmotte, V.; Zhai, P.; Pirani, P.; Connors, S.L.; Péan, C.; Berger, S.; Caud, N.; Chen, Y.; Goldfarb, L.; Gomis, M.I.; et al. IPCC, 2021: Climate Change 2021: The Physical Science Basis. Contribution of Working Group I to the Sixth Assessment Report of the Intergovernmental Panel on Climate Change; Cambridge University Press: Cambridge, UK, 2021; in press.

2. Shukla, P.R.; Skea, J.; Calvo Buendia, E.; Masson-Delmotte, V.; Pörtner, H.O.; Roberts, D.C.; Zhai, P.; Slade, R.; Connors, S.; Van Diemen, R. IPCC, 2019: Climate Change and Land: An IPCC Special Report on Climate Change, Desertification, Land Degradation, Sustainable Land Management, Food Security, and Greenhouse Gas Fluxes in Terrestrial Ecosystems; Intergovernmental Panel on Climate Change (IPCC): Geneva, Switzerland, 2019.

3. Mendelsohn, R.O.; Nordhaus, W.D.; Shaw, D. The Impact of Global Warming on Agriculture: A Ricardian Analysis. Am. Econ. Rev. 1994, 84, 753-771.

4. USDA. 2017 Census of Agriculture Highlights; US Department of Agriculture: Washington, DC, USA, 2017.

5. USDA. 2017 Census of Agriculture; US Department of Agriculture: Washington, DC, USA, 2019.

6. Roenfeldt, S. You Can't Afford to Ignore Heat Stress. Dairy Herd Manag. 1998, 35, 6-12.

7. Hristov, A.N.; DeGaetano, A.T.; Rotz, C.A.; Hoberg, E.; Skinner, R.H.; Felix, T.; Li, H.; Patterson, P.H.; Roth, G.; Hall, M.; et al. Climate change effects on livestock in the Northeast US and strategies for adaptation. Clim. Chang. 2017, 146, 33-45. [CrossRef]

8. St-Pierre, N.; Cobanov, B.; Schnitkey, G. Economic Losses from Heat Stress by US Livestock Industries. J. Dairy Sci. 2003, 86, E52-E77. [CrossRef]

9. Nienaber, J.; Hahn, G. Livestock production system management responses to thermal challenges. Int. J. Biometeorol. 2007, 52, 149-157. [CrossRef]

10. Sejian, V.; Maurya, V.P.; Kumar, K.; Naqvi, S.M.K. Effect of multiple stresses on growth and adaptive capability of Malpura ewes under semi-arid tropical environment. Trop. Anim. Health Prod. 2012, 45, 107-116. [CrossRef]

11. Nardone, A.; Ronchi, B.; Lacetera, N.; Ranieri, M.; Bernabucci, U. Effects of climate changes on animal production and sustainability of livestock systems. Livest. Sci. 2010, 130, 57-69. [CrossRef]

12. Intergovernmental Panel on Climate Change. Climate Change 2014: Impacts, Adaptation, and Vulnerability-Part B: Regional AspectsContribution of Working Group II to the Fifth Assessment Report of the Intergovernmental Panel on Climate Change; Barros, V.R., Field, C.B., Dokken, D.J., Mastrandrea, M.D., Mach, K.J., Bilir, T.E., Chatterjee, M., Ebi, K.L., Estrada, Y.O., Genova, R.C., et al., Eds.; Cambridge University Press: Cambridge, UK; New York, NY, USA, 2014; ISBN 978-1-107-68386-0.

13. Intergovernmental Panel on Climate Change. Climate Change 2001: Impacts, Adaptation and Vulnerability. Contribution of Working Group II to the Third Assessment Report of the Intergovernmental Panel on Climate Change; Cambridge University Press: Cambridge, UK, 2001.

14. Herrero, M.; Thornton, P.; Kruska, R.; Reid, R. Systems dynamics and the spatial distribution of methane emissions from African domestic ruminants to 2030. Agric. Ecosyst. Environ. 2008, 126, 122-137. [CrossRef]

15. Hoffmann, I. Climate change and the characterization, breeding and conservation of animal genetic resources. Anim. Genet. 2010, 41, 32-46. [CrossRef]

16. Mu, J.E.; McCarl, B.A.; Wein, A.M. Adaptation to climate change: Changes in farmland use and stocking rate in the U.S. Mitig. Adapt. Strat. Glob. Chang. 2013, 18, 713-730. [CrossRef]

17. Zhang, Y.W.; Hagerman, A.D.; McCarl, B.A. Influence of climate factors on spatial distribution of Texas cattle breeds. Clim. Chang. 2013, 118, 183-195. [CrossRef]

18. Cho, S.J.; McCarl, B.A. Climate change influences on crop mix shifts in the United States. Sci. Rep. 2017, 7, 40845. [CrossRef]

19. Seo, S.N.; Mendelsohn, R.O. Measuring Impacts and Adaptations to Climate Change: A Structural Ricardian Model of African Livestock Management. Agric. Econ. 2008, 38, 151-165. [CrossRef]

20. Tubiello, F.; Rosenzweig, C.; Goldberg, R.; Jagtap, S.; Jones, J. Effects of climate change on US crop production: Simulation results using two different GCM scenarios. Part I: Wheat, potato, maize, and citrus. Clim. Res. 2002, 20, 259-270. [CrossRef] 
21. Ovalle-Rivera, O.; Läderach, P.; Bunn, C.; Obersteiner, M.; Schroth, G. Projected Shifts in Coffea arabica Suitability among Major Global Producing Regions Due to Climate Change. PLoS ONE 2015, 10, e0124155. [CrossRef]

22. Hijmans, R.J. The effect of climate change on global potato production. Am. J. Potato Res. 2003, 80, 271-279. [CrossRef]

23. Machovina, B.; Feeley, K.J. Climate change driven shifts in the extent and location of areas suitable for export banana production. Ecol. Econ. 2013, 95, 83-95. [CrossRef]

24. Havlík, P.; Valin, H.; Mosnier, A.; Obersteiner, M.; Baker, J.S.; Herrero, M.; Rufino, M.C.; Schmid, E. Crop Productivity and the Global Livestock Sector: Implications for Land Use Change and Greenhouse Gas Emissions. Am. J. Agric. Econ. 2012, 95, 442-448. [CrossRef]

25. Mu, J.E.; Sleeter, B.M.; Abatzoglou, J.T.; Antle, J.M. Climate impacts on agricultural land use in the USA: The role of socio-economic scenarios. Clim. Chang. 2017, 144, 329-345. [CrossRef]

26. Ghahramani, A.; Kingwell, R.; Maraseni, T.N. Land use change in Australian mixed crop-livestock systems as a transformative climate change adaptation. Agric. Syst. 2020, 180, 102791. [CrossRef]

27. Mu, J.E.; McCarl, B.A.; Sleeter, B.; Abatzoglou, J.T.; Zhang, H. Adaptation with climate uncertainty: An examination of agricultural land use in the United States. Land Use Policy 2018, 77, 392-401. [CrossRef]

28. Kabubo-Mariara, J. Climate change adaptation and livestock activity choices in Kenya: An economic analysis. Nat. Resour. Forum 2008, 32, 131-141. [CrossRef]

29. Seo, S.N.; McCarl, B.A.; Mendelsohn, R. From beef cattle to sheep under global warming? An analysis of adaptation by livestock species choice in South America. Ecol. Econ. 2010, 69, 2486-2494. [CrossRef]

30. Mader, T.L.; Frank, K.L.; Harrington, J.A., Jr.; Hahn, L.G.; Nienaber, J.A. Potential climate change effects on warm-season livestock production in the Great Plains. Clim. Chang. 2009, 97, 529-541. [CrossRef]

31. Craine, J.M.; Elmore, A.; Olson, K.C.; Tolleson, D. Climate change and cattle nutritional stress. Glob. Chang. Biol. 2010, 16, 2901-2911. [CrossRef]

32. Hahn, G.L. Dynamic responses of cattle to thermal heat loads. J. Anim. Sci. 1997, 77, 10-20. [CrossRef]

33. Seo, S.N.; McCarl, B. Managing Livestock Species under Climate Change in Australia. Animals 2011, 1, 343-365. [CrossRef]

34. Seo, S.N. Adapting to extreme climates: Raising animals in hot and arid ecosystems in Australia. Int. J. Biometeorol. 2014, 59, 541-550. [CrossRef] [PubMed]

35. Godde, C.; Dizyee, K.; Ash, A.; Thornton, P.; Sloat, L.; Roura, E.; Henderson, B.; Herrero, M. Climate change and variability impacts on grazing herds: Insights from a system dynamics approach for semi-arid Australian rangelands. Glob. Chang. Biol. 2019, 25, 3091-3109. [CrossRef]

36. Schlenker, W.; Hanemann, W.M.; Fisher, A.C. The Impact of Global Warming on U.S. Agriculture: An Econometric Analysis of Optimal Growing Conditions. Rev. Econ. Stat. 2006, 88, 113-125. [CrossRef]

37. Redfearn, D.D.; Bidwell, T.G. Stocking Rate: The Key to Successful Livestock Production. $2006 . \quad$ Available online: https: / / extension.okstate.edu/fact-sheets / print-publications/pss/stocking-rate-the-key-to-successful-livestock-productionpss-2871.pdf (accessed on 17 November 2021).

38. Adams, D.M.; Alig, R.J.; McCarl, B.A.; Murray, B.C. FASOMGHG Conceptual Structure, and Specification: Documentation 2005. Available online: https:/ / docplayer.net/62907502-Fasomghg-conceptual-structure-and-specification-documentation.html (accessed on 17 November 2021).

39. Mullahy, J. Multivariate Fractional Regression Estimation of Econometric Share Models. J. Econ. Methods 2015, 4, 71-100. [CrossRef]

40. Murteira, J.M.R.; Ramalho, J. Regression Analysis of Multivariate Fractional Data. Econ. Rev. 2014, 35, 515-552. [CrossRef]

41. Ramalho, E.A.; Ramalho, J.J.S.; Murteira, J.M.R. Alternative Estimating and Testing Empirical Strategies for Fractional Regression Models. J. Econ. Surv. 2011, 25, 19-68. [CrossRef]

42. Papke, L.E.; Wooldridge, J.M. Econometric Methods for Fractional Response Variables with an Application to 401(K) Plan Participation Rates. J. Appl. Econom. 1996, 11, 619-632. [CrossRef]

43. Long, J.S.; Freese, J. Regression Models for Categorical Dependent Variables Using Stata; Stata Press: College Station, TX, USA, 2006; Volume 7.

44. Fisher, A.C.; Hanemann, W.M.; Roberts, M.J.; Schlenker, W. The Economic Impacts of Climate Change: Evidence from Agricultural Output and Random Fluctuations in Weather: Comment. Am. Econ. Rev. 2012, 102, 3749-3760. [CrossRef]

45. USDA's Economic Research Service USDA ERS Farm Resource Regions. Available online: https://www.ers.usda.gov/webdocs/ publications / 42298/32489_aib-760_002.pdf?v=42487 (accessed on 23 October 2021).

46. US Department of Agriculture. Quick Stats 2.0; National Agricultural Statistics Service, US Department of Agriculture: Washington, DC, USA, 2018.

47. Menne, M.J.; Durre, I.; Vose, R.S.; Gleason, B.E.; Houston, T.G. An Overview of the Global Historical Climatology Network-Daily Database. J. Atmos. Ocean. Technol. 2012, 29, 897-910. [CrossRef]

48. USDA's Economic Research Service Milk Cost of Production Estimates. Available online: https://www.ers.usda.gov/dataproducts/milk-cost-of-production-estimates/ (accessed on 21 August 2021). 
49. USDA. Land Values 2021 Summary; US Department of Agriculture: Washington, DC, USA, 2021; p. 22.

50. US Department of the Interior, Bureau of Reclamation, Technical Services Center. Downscaled CMIP3 and CMIP5 Climate and Hydrology Projections: Release of Downscaled CMIP5 Climate Projections, Comparison with Preceding Information, and Summary of User Needs; US Department of the Interior Denver: Lakewood, CO, USA, 2013; p. 47. 